\title{
Det samfundsnyttige landbrug: Nye bæredygtige forretningsmodeller for landbrug i Danmark
}

\author{
Af Mette Vinther Larsen \& Charlotte Oland Madsen *)
}

\begin{abstract}
Resumé
I denne artikel udfoldes en ny strømning inden for økonomisk tænkning og teori. Baseret på bæredygtige og systemteoretiske tilgange udfordres de klassiske økonomiske teorier og giver nye måder for ledere at arbejde innovativt med bæredygtige forretningsmodeller. Formålet med artiklen er at udfolde, hvordan bæredygtig økonomisk teori kombineret med teorier om innovation af bæredygtige forretningsmodeller kan sætte spørgsmålstegn ved de taget-for-givet forestillinger om økonomisk styring, der præger beslutningsprocesserne i danske virksomheder. Gennem to cases undersøges og eksemplificeres der muligheder og begrænsninger for at skabe bæredygtige forretningsmodeller. Artiklen tager udgangspunkt i projektet "Det samfundsnyttige landbrug", der har sat fokus på at udvikle nye forretningsmodeller for økologisk landbrug i Danmark.
\end{abstract}

\section{Emneord}

Forretningsmodeller, doughnutøkonomi, bæredygtighed, økologi

*) Mette Vinther Larsen er professor MSO, ph.d. ved Institut for Økonomi og Ledelse på Aalborg Universitet. Charlotte Øland Madsen er lektor, ph.d., samme sted. 


\section{A. Introduktion}

\section{Baggrund}

I denne artikel udfoldes der en ny bæredygtig økonomisk teori, udviklet af Kate Raworth (2017). Raworth's Doughnut-model bruges til at illustrere et teoretisk skift fra klassiske økonomiske teorier om vækst og rationalisering (Marshal, 1890; Smith, 1776). I artiklen uddybes den nye tilgang til bæredygtig økonomisk teori med en ny teoretisk tilgang til udvikling af bæredygtige forretningsmodeller (Bocken et. al., 2014; Joyce \& Paquin, 2016; Nicoletti, 2019; Raworth, 2017). Artiklen fokuserer på, hvordan nye bæredygtige forretningsmodeller kan anspore ledere til at tænke anderledes om mulighederne for at udvikle eksisterende og nye virksomheder med fokus på bæredygtighed.

Ifølge Joyce \& Paquin (2016: 1474) giver en øget opmærksomhed på de miljøudfordringer verden står overfor anledning til, at virksomheder kan og bør gentænke deres forretningsmodeller. I deres optik kan netop disse udfordringer ses som muligheder for, at organisationer øger deres engagement i bæredygtigheds-orienteret innovation. De foreslår, at den klassiske Business Model Canvas (BMC) model udviklet af Ostervalder \& Pigneur i 2010, udvides til en Trippel Layer BMC (TLBMC), hvor den oprindeligt økonomisk orienterede BMC også inkluderer tanker om miljømæssigog social-/værdiskabelse. Den miljømæssige værdiskabelse kan udvide det klassiske økonomiske fokus på omsætning og omkostninger med tanker om, hvordan virksomheden eller organisationen kan medvirke til at forbedre miljøet eller formindske den miljømæssige indvirkning, dens aktiviteter har på miljøet. Den sociale værdiskabelse sker gennem fokus på samarbejde med aktører og organisationer i det omgivende samfund (Bocken et. al., 2014; Brix 2020; Joyce \& Paquin, 2016; Nicoletti, 2019; Raworth, 2017).

\section{Formål}

I denne artikel fokuseres der på forskningsspørgsmålet: Er det realistisk og praktisk muligt at implementere Raworth's Doughnut-model gennem udvikling af bæredygtige forretningsmodeller baseret på TLBMC modellen?

Gennem to udvalgte eksemplar cases (Bronk et. al., 2013) fra projektet "Det Samfundsnyttige Landbrug" vil artiklen udfolde, hvordan konturerne af fremtidens bæredygtige landbrug måske kan komme til at se ud. Casene illustrerer, hvordan nytænkning af producent / forbrugerrelationer, generationsskifter samt en tættere relation til det omgivende samfund kan give nye muligheder for landbruget, som i disse år er trængt både økonomisk og på deres afstand til forbrugerne (SEGES 2016; DN 2017). 


\section{B. Teoretisk grundlag}

\section{Bæredygtig økonomisk teori}

Raworth (2017) skriver, at den ensidige fokusering på økonomisk vækst i det 20 århundrede, som svaret på alle det moderne samfunds problematikker indenfor forurening, ulighed og livskvalitet har resulteret i store udfordringer for verdens økonomi og jordens økosystem. Mantraet i den økonomiske teori har været, at øget vækst til slut vil resultere i en ny balance, hvor væksten så at sige vil rydde op efter sig selv. Dette synspunkt gør Kate Raworth (2017) op med og har udarbejdet en ny økonomisk model baseret på systemteoretisk tænkning - Doughnut-modellen.

Raworth's Doughnut-model udgør ikke blot en ny måde at gentænke de grundantagelser fra den økonomiske teori, som tages for givet, når politikere og verdensledere udtaler sig og træffer beslutninger om verdensøkonomi og nationaløkonomi. Modellen giver også baggrund for at tænke anderledes i små som store virksomheder, der står overfor et valg om at fortsætte beslutningstagning og handlinger baseret på økonomiske modeller, der primært blev udtænkt for over 100 år siden.

Kate Raworth (2017) anbefaler, at vi gør op med et klassisk fokus på markedsmekanismer fra den økonomiske teori og ændrer dette til at tænke på markedet som en organisme. Dette skift betyder, ifølge Raworth, at vi stopper med at tænke markedet og afsætning som en lineær mekanisme styret af udbud og efterspørgsel udviklet af Alfred Marshal i 1890 og underforstået styret af Adam Smiths (1776) usynlige hånd og i stedet begynder at forstå den komplekse dynamiske organisme, der ligger bag ved dette.

Den grundlæggende antagelse af udbud og efterspørgsel som to linjer, der mødes på et specifikt og optimalt punkt, kan ikke forklare de komplekse adaptive og emergente balancer og ubalancer, der styrer udviklingen i pris og efterspørgsel. Det har den alvorlige konsekvens, at denne grundlæggende antagelse styrer adfærden i industrien, således at der bliver fokuseret på øget produktion til lavere omkostninger som den rette måde at øge indtjeningen.

Raworth's teori kritiserer yderligere en af de grundlæggende antagelser i økonomisk teori, det rationelle menneske. Langt de fleste klassiske økonomiske teorier er baseret på den antagelse, at investorer og forbrugere er Homo economicus - isolerede, beregnende, konkurrerende og umættelige (Raworth, 2017: 95). Det er ifølge Raworth denne definition af os som forbrugere, der i høj grad influerer den måde, vi definerer os på selv, men også influerer, hvordan virksomhedsledere definerer aftagerne af deres produkter. Men hvad sker der med udviklingen af forretningsmodellerne, hvis denne antagelse ændres til; "Homo heuristicus", "Homo reciprocans", "Homo altruisticus" og "Homo socialis"? (Raworth, 2017: 128). Når dette sker, lægges der vægt på 
andre fortolkninger, og der gives rum for andre måder at betragte investorer og forbrugere og bane vejen for udvikling af mere bæredygtige forretningsmodeller.

\section{Doughnut økonomi}

Lovgivning og socialt pres omkring lige vilkår for alle påvirker HR-afdelinger i fortsat højere grad. Udviklingen skyldes ifølge Guillén et al. (2018) blandt andet, at de karrieremæssige ønsker og aspirationer er blevet mere lige mellem mænd og kvinder. Samtidig opstilles i flere lande lovmæssige krav om håndtering og ansvar for minoriteter i samfundet (Konrad, Yang \& Maurer, 2016).

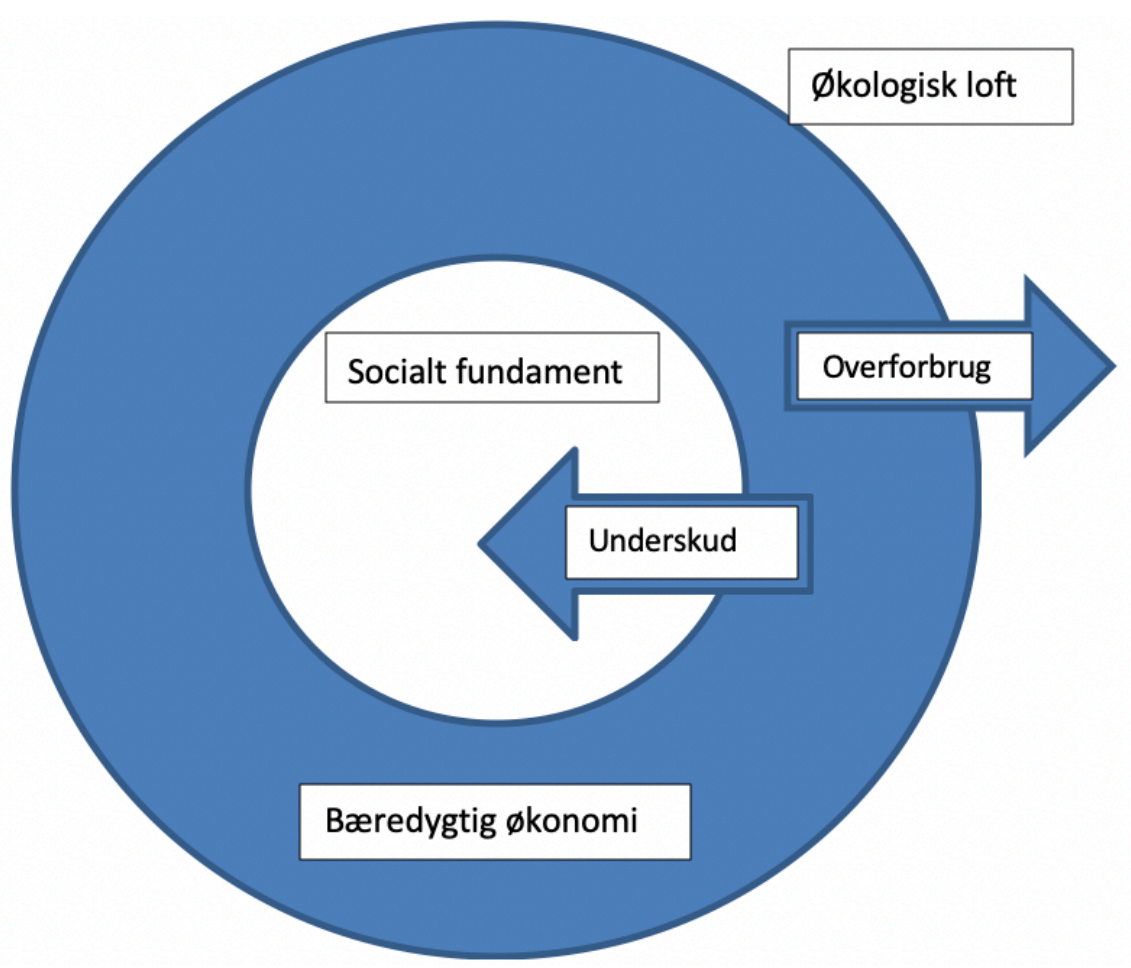

Figur 1: Doughnut-modellen (Inspireret af Doughnut-modellen, Kate Raworth, 2017: 44)

Doughnut-modellen består af to koncentriske cirkler. Den inderste ring i modellen beskriver det sociale fundament, som alle mennesker har brug for. I denne del af modellen skal det sikres, at alle mennesker på jorden får opfyldt deres basale behov for i form af adgang til rent vand, mad, indtægt, arbejde, energi, husly, sundhed. Endvidere skal der være midler til at finansiere samfund, der sikrer borgerne adgang til uddannelse, adgang til et fungerende sundhedsvæsen, indtægt og arbejde, social lighed, politisk indflydelse, fred og retfærdighed. Samtidig beskriver den yderste cirkel i modellen relationen mellem opfyldelsen af de menneskelige behov og de økonomiske aktiviteter, der ifølge Raworth (2017) i nogen grad allerede rammer det økologisk loft for, hvor meget vores planet kan holde til. Tanken i modellen er derfor, at vi skal opretholde en ligevægt mellem disse to forhold og sørge for, at de basale menneskelige behov understøttes, samtidig med at vi ikke driver rovdrift på og forurener jordens ressourcer. Budskabet er, at hvis denne balance, beskrevet som en doughnut 
lignende ring, ikke findes, vil der på længere sigt ikke være en bæredygtig fremtid for os på jorden. Disse tanker er for så vidt ikke nye. Det nye er, at der sættes spørgsmålstegn ved, om økonomisk vækst er den eneste måde at sikre, at vi forbliver i den bæredygtige ring (Raworth, 2017).

En litteratursøgning i september 2020 via Google Scholar på kritik af Raworth's doughnut-model viser, at meget lidt forskning endnu er publiceret omkring denne radikalt anderledes økonomiske model. Det anbefales dog i International Journal of Economics, Management and Accounting, at modellen undersøges nærmere teoretisk og empirisk, også med en kritisk vinkel (Indrawan, 2018). I denne artikel er fokus primært på at udfolde de nye økonomiske ideer i modellen gennem to eksemplar cases (Bronk et. al., 2013) fra "Det samfundsnyttige landbrug" og vise, hvordan bæredygtige forretningsmodeller kan udvikles i praksis.

\section{Bæredygtige forretningsmodeller}

Litteraturen om forretningsmodeller og udviklingen af disse i virksomheder har de seneste årtier floreret som en kernekomponent til at opnå forretningsmæssig succes (Chesbrough, 2010; Osterwalder \& Pigneur, 2010; Richardson, 2008). En af de dominerende tilgange Business Model Canvas modellen udviklet af Osterwalder \& Pigneur (2010), blev udviklet som en model for innovation af forretningsmodeller på baggrund af klassisk økonomisk teori.

Tankerne om udvikling og innovation af bæredygtige forretningsmodeller har det seneste årti været et fokuspunkt for forskere (Bocken et. al., 2014; Geissdoerfer et. al., 2018; Porter \& Kramer, 2011; Stubbs \& Cocklin, 2008). Geissdoerfer et. al. (2018) konkluderer, at et øget ledelsesfokus på udvikling og innovation af bæredygtige forretningsmodeller vil kunne øge succesraten for opstartsvirksomheder med fokus på bæredygtighed samt øge udviklingen af ny teknologi, der understøtter bæredygtig produktion. Brix (2020), der undersøger implementeringsprocessen af nye bæredygtige strategier, finder samtidig, at det er vigtigt, at medarbejderne også involveres i disse processer. Bocken et. al. (2014) foreslår i deres litteraturgennemgang af feltet, at innovation af bæredygtige forretningsmodeller kan identificeres i tre arketyper: 1) teknologiske udviklinger, der skåner miljøet, når varer produceres 2) sociale tiltag, der understøtter samfundet, samt 3) organisatorisk nytænkning, hvor andelsselskaber, crowdfunding og socialøkonomisk virksomhed kommer i fokus.

Joyce \& Paquin (2016) har med udgangspunkt i Osterwalder \& Pigneur's (2010) BMC-model udviklet en tilgang til bæredygtig forretningsmodel innovation, som betyder, at den oprindelige BMC-model suppleres med to yderligere lag. I det oprindelige første lag, der understøtter innovation af forretningsmodeller ud fra klassisk økonomisk teori, udvikles der forretningsmodeller på baggrund af, hvordan virksomhedens kerneaktiviteter kan integreres for at skabe værdi for kunderne. 
Kerneaktiviteterne understøttes af virksomhedens værdikæde og aktiviteter med dens interessent netværk, samt hvordan virksomheden kan skabe værdi og overskud gennem disse samarbejder.

Med udgangspunkt i en simpel profit-maksimerings tankegang vil den oprindelige BMC-model ikke kunne understøtte virksomheders arbejde med bæredygtighed. Joyce \& Paquin (2016) foreslår derfor, at det økonomiske fokus suppleres med tankegangen om den tredobbelte bundlinje (Savitz, 2012), hvor miljøhensyn og sociale formål tænkes med ind som en del af den værdi, en virksomhed kan bidrage med.

Innovating towards more sustainable business models requires developing new business models which go beyond an economic focus to one which generate and integrates economic, environmental and social value through an organisation's actions.

(Joyce \& Paquin, 2016: 1476)

I dette citat understreges det, som også Raworth (2017) argumenterer for, at bæredygtighed ikke blot skal betragtes ud fra en ren filliantropisk tilgang, men at den økonomiske tilgang kan kombineres med miljøhensyn og sociale formål på en og samme tid.

I det andet lag af TLBMC fokuseres der på miljøhensyn, hvor en livscyklustankegang for de produkter, der produceres og konsumeres, bør integreres i forretningsmodellen. Her kan produktionen i hele værdikæden tænkes ind, samt hvordan produktet forbruges hos kunderne. Dette kan f.eks. ske gennem teknologiske innovationer af genanvendelig emballage. Kernen i spørgsmålet bliver her for virksomhederne, hvordan de gennem forretningsmodel innovation kan reducere negative, samt øge positive miljøpåvirkninger.

Det tredje lag i TLBMC - modellen handler om den sociale værdi, en virksomhed kan tilføje til både dens interne og eksterne interessentnetværk, samt den værdi den skaber for det omgivende samfund. Spørgsmålet bliver, hvordan virksomheden kan medvirke til skabelse af social værdi, for dens ansatte og andre interessenter og gennem tættere samarbejdsrelationer med partnere, kunder og det lokale samfund?

Den afgørende pointe hos Joyce \& Paquin (2016) er dog, at de tre lag, økonomisk, miljøhensyn, og social værdi ofte teoretisk og i praksis betragtes som tre uafhængige lag, der ikke er vertikalt integrerede. Det er først, når lagene tænkes ind i forretningsmodellen som vertikalt integrerede, at muligheden for bæredygtig forretningsmodelinnovation opstår. Men som vi tidligere skrev, så er forskningsspøgsmålet, der udfoldes i denne artikel: Er det realistisk og praktisk muligt at implementere Raworth's Doughnut-model gennem udvikling af bæredygtige forretningsmodeller 
baseret på TLBMC modellen? Dette vil vi nu udfolde gennem to eksemplar cases om udvikling af nye forretningsmodeller for økologiske landbrug.

\section{Et trængt dansk landbrug}

\section{Case introduktion}

Det danske landbrug er i disse år er præget af produktionsfaciliteter, der konstant vokser og skal fornyes, for at leve op til et ønske om rationaliseringsgevinster gennem stordriftsfordele. Dette betyder, at omkostningerne ved at drive landbrug stiger samtidig med, at priserne på varerne fluktuerer betydeligt (SEGES, 2016; DN, 2017). Dette klassiske økonomiske dilemma mellem udbud og efterspørgsel gør, at landmænd, konventionelle såvel som økologiske, er økonomisk trængt. Jorden og dermed grundlaget for produktionen bliver koncentreret på færre og færre hænder, og generationsskifte kan derfor virke uoverskueligt på de enkelte bedrifter. Samtidig er specielt det konventionelle landbrug trængt af skandaler, forurening af vandmiljøet, øget brug af giftstoffer og penicillin, samt sygdomme og smitterisiko i deres produkter, der har gjort forbrugerne bekymrede for miljøskadelige konsekvenser, fødevaresikkerhed samt dyrevelfærd (DN, 2017).

Gennem den sidste del af det 20. århundrede samt begyndelsen af det 21. århundrede, er der sket en vækst i andelen af økologiske landbrug. Danmark har et salg af økologiske fødevareprodukter svarende til 9,7\% af det samlede fødevaresalg i dagligvarehandlen og en total omsætning til detailhandlen, grossister/catering/, restauranter og nethandel på 11,8 mia. kr. (DN, 2017). Denne produktion er på grund af de øgede omkostninger i produktionen ikke i samme grad styret af den ovenstående lineære økonomiske tænkning. Her har det været nødvendigt at udvikle produkter, der kan siges at have øget værdi for kunderne og skabe en niche i konkurrencen med de konventionelle landbrugsprodukter. Hvor den øgede merværdi for forbrugerne skabes gennem et ønske om sundere fødevarer, et sundere miljø samt øget dyrevelfærd.

At det har været muligt at bryde med det markedsdrevne princip, kan ses som et eksempel på det Raworth (2017) omtaler som muligheden for gennem små ændringer at skabe større forandringer. Et eksempel på, at indtjeningen på landbrugsvarer ikke blot afhænger af udbud og efterspørgsel, men også af den miljøbevidste forbruger.

Men såvel konventionelle som økologiske landmænd er stadig trængt økonomisk og derfor har Villumfonden og Veluxfonen støttet projektet "Det samfundsnyttige Landbrug", der udmøntes gennem et nært samarbejde med Økologisk Landsforening, hvor der gives økonomisk og rådgivningsmæssig støtte til udvikling af nye forretningsmodeller for det økologiske landbrug. (http://samfundsnyttigtlandbrug.dk/om-projektet). 
En af forfatterne til denne artikel har fulgt Økologisk Landsforenings projektledere i arbejdet med at implementere de udvalgte cases i projektet gennem et år og har gennem deltagelse i møder med projektlederne samt interviews med disse fulgt processen. De temaer, der tages op i denne artikel, oprinder i dette aktionsforskningsprojekt (Hersted \& Madsen, 2018). Det er dog vigtigt at understrege, at det følgende bygger på forskernes egen viderefortolkning og analyse af, hvordan "Det samfundsnyttige landbrug" og udvalgte eksemplar cases kan illustrere nogle af Kate Raworth's teoretiske pointer (Bronk et. al., 2013). Men da de blev udviklet, havde de ikke dette teoretiske udgangspunkt. Endvidere er det vigtigt, at læseren ikke blot betragter dette som en landbrugsspecifik case, men at opgøret med grundantagelserne i den klassiske økonomiske teori kan anvendes til at gentænke bæredygtige forretningsmodeller i et langt bredere spekter (Bocken et. al., 2014; Brix, 2020; Geissdoerfer et. al., 2018; Joyce \& Paquin, 2016; Porter \& Kramer, 2011; Raworth, 2017; Stubbs \& Cocklin, 2008).

\section{Case 1: Gården i Byen}

Gården i byen: Egholm Folkefarm er et projekt på øen Egholm, der ligger tæt på Aalborg. Sissel Hermansen og Thomas Larsen har købt et 30ha konventionelt landbrug på Egholm. Der er påbegyndt omlægning til økologisk landbrug, og det er håbet, at det vil brede sig til hele Egholm og omfatte 500ha økologisk drift. Gården i byen organiseres som et andelsselskab, hvor ca. 60 familier i nærområdet får mulighed for at købe en andel. Gennem fællesarrangementer og temamøder ønskes der en tæt relation til andelshaverne, der også får indflydelse på, hvad der produceres. Endvidere etableres samarbejde med kommunens børnehaver og skoler, og det er ønsket at oprette en skolekøkkenhave, hvor børnene kan lære om økologisk landbrug. Der er også planer om at ansætte medarbejdere i jobprøvning i samarbejde med Aalborg Kommune. I projektet Gården i byen: Egholm Folkefarm har der været fokus på at skaffe alternativ finansiering til jordopkøb samt opstart og omlægning til økologisk drift. Den nye forretningsmodel går ud på at skaffe kapital gennem udskrivelse af aktier. En aktie kan købes for $5000 \mathrm{kr}$.

(http://samfundsnyttigtlandbrug.dk/cases/egholm-folkefarm-gaarden-i-byen).

\section{Case 2: SamsØkologisk}

I projektet SamsØkologisk er der oprettet en jordbrugsfond, med det formål at rejse kapital gennem blandt andet crowdfunding til opkøb af landbrugsjord på Samsø. Fondens formål er at sætte fokus på økologi og bæredygtighed. Det er ønsket med projektet at gå nye veje omkring ejerskabsforhold, hvor jorden ejes af fonden, men drives via forpagtere med økologisk drift. Projektet understøtter etableringen af permakulturer/skovhaver samt levefællesskaber baseret på økologi og bæredygtighed. Der ses en tæt relation til Samsø’s brand som energiø og økoturisme. 


\section{Analyse udvikling af bæredygtige forretningsmodeller}

I ovenstående beskrivelse af udfordringerne i landbruget i Danmark ses det tydeligt, at ønsket om vækst primært koncentreres om øget produktion, med mange økonomiske, miljømæssige og sociale udfordringer til følge. Men hvad sker der, hvis vi ændrer på den grundlæggende tanke om, at øget produktion og konkurrence på pris er den eneste måde at drive økonomisk og bæredygtigt landbrug på?

Hvordan tænker man nyt omkring dette dominerende paradigme og ikke mindst, hvordan kan det være muligt at finansiere dette $\mathrm{i}$ et samfund, hvor fokus på forretningsplaner, overskud på bundlinjen samt afhængigheden af at låne penge til driften er fremherskende? Set i dette lys er finansiering af nye små økologiske landbrug næsten umulige for unge landmænd.

\section{1. Økonomisk \& teknologisk udvikling}

I første lag af TLBMC-modellen fokuseres der på nytænkning af de klassiske økonomiske og teknologiske rationaler for produktion (Joyce \& Paquin, 2016). I projektet "Det samfundsnyttige landbrug" er der blevet tænkt anderledes omkring de økonomiske rammer for at drive økologisk landbrug i Danmark. Flere af projekterne i "Det samfundsnyttige Landbrug" har generationsskifte samt opretholdelse af den økologiske landbrugsdrift som fokusområde. Det er dog ikke umiddelbart en nem løsning at finde alternativer til finansiering, og i den efterfølgende evalueringsrapport udtrykkes det, at "Flere af respondenterne giver udtryk for, at mangel på finansiering dels hæmmer udviklingen, men også rammer projekthaverne på deres tidsmæssige ressourcer, som igen så hæmmer den ønskede udvikling. " (Asmussen T., 2017: 8).

Dette giver derfor, set i relation til Raworth's økonomiske paradigmeskift, anledning til at reflektere over, hvor svært det synes at være at finansiere tiltag af denne type. Der er i projekterne prøvet flere forskellige muligheder af, og disse har givet anledning til fremgang, men økonomien er stadig et vigtigt punkt at fokusere på, hvis disse projekter skal være økonomisk bæredygtige i fremtiden.

Der er dog noget, der tyder på, at øget investering i økologi og landbrugsjord er muligt og vil se en stigning i de kommende år. Egholmfolkefarm samt SamsØkologisk er kommet videre med deres projekter, og i kølvandet på SamsØkologisk er der nu også etableret en landsdækkende Danmarks Økologiske Jordbrugsfond. Her udstedes der aktier til 25.000 kr. og et større million beløb er samlet ind (www.jordbrugsfond.dk). Anvendelsen af ny teknologi, crowdfunding, har muliggjort, at budskabet om projekterne er kommet bredt ud og giver andre muligheder for at sætte projekter i gang og skaffe økonomiske midler. Da investering i økologisk landbrugsjord og produktion ikke i sig selv har et økonomisk afkast som formål, giver det her mening at tale om altruistiske investeringer. Noget der ifølge Raworth's (2017) teori gør det muligt at gentænke menneskelig 
adfærd som andet og mere end rationel nytte optimering. Det viser, at innovation af bæredygtige forretningsmodeller giver anledning til at gentænke en af de grundlæggende antagelser i økonomisk teori, det rationelle menneske. Set i en TLBMC-tilgang til innovation af bæredygtige forretningsmodeller i det første økonomiske lag giver dette anledning til, at der integreres alternative finansieringsmuligheder (Joyce \& Paquin, 2016).

\section{Miljøhensyn}

I TLBMC modellens andet lag fokuseres der på inddragelse af miljøhensyn i forretningsmodellen (Joyce \& Paquin, 2016). Som omtalt kritiserer Raworth (2017) samt Bocken et. al. (2014) den antagelse, at det udelukkende er pris og efterspørgsel, der bør styre virksomheders tilgang til produktion af varer.

Alternativet kan være, som Case 1, Egholm Folkefarm illustrerer, at der tages udgangspunkt i knytte forbrugerne tættere til selve produktionen af landbrugsvarer. I casen sker dette gennem køb af aktier med argumentet, om at man kan blive medejer af en økologisk gård, der arrangeres events, hvor byboer kan komme på besøg og se, hvordan varerne produceres. Den gensidige tillid mellem producent og forbruger gør det muligt at bryde med tanken om forbrugerne som selvoptimerende og prisfokuserende individer. Samtidig kan indkøbet knyttes til en ny forbrugsidentitet, der er tæt knyttet til værdier om fællesskab, bæredygtighed samt omsorg for familiens sundhed.

Set i forhold til case 1 og 2 vil fokus på miljøhensyn, der allerede er lagt på bæredygtig økologisk produktion i høj grad kunne siges allerede at være indarbejdet i forretningsmodellen. Hensyn til bæredygtige produktionsmetoder, dyrevelfærd og genanvendelse af restprodukter er en del af det grundlæggende formål med, at disse organisationer eksisterer. Integrationen af miljøhensyn i TLBMC modellens andet lag kan derfor siges at være indlejret fra starten (Joyce \& Paquin, 2016).

\section{Sociale formål}

I TLBMC modellens tredje lag arbejdes der med den sociale værdi af forretningsmodellen (Joyce \& Paquin, 2016). Gennem udvikling af utraditionelle samarbejder mellem forskellige interessenter, det, der også betegnes kollaborative forretningsmodeller, muliggøres yderligere innovation af konceptet for forretningsmodeller (Kringelum, 2017). For Kate Raworth (2017) handler dette om, at producenterne skal gøre op med et ensidigt fokus på egen produktion og begynde at se sig selv som en del af deres lokalsamfund. Det helt nye i de to udvalgte cases er netop det intensive arbejde med det sidste og tredje lag i TLBMC-modellen, samarbejdet mellem de økologiske landmænd og andre sociale interessenter, både i lokalmiljøet, men også set i en større samfundsmæssig sammenhæng (Joyce \& Paquin, 2016).

I case 1, Egholm Folkefarm, har der været fokus på at invitere lokale skoler og børnehaver til at besøge farmen. På den måde inddrages lokalsamfundet gennem et samarbejde med de kommunale 
institutioner. Ideen om at inddrage børnene giver også mulighed for at påvirke forældrenes indkøbsadfærd. Yderligere er der etableret samarbejde med kommunen om at henvise borgere med behov for arbejdsprøvning.

I case 2, SamsØkologisk, har der set i et lokalt perspektiv været fokus på at skabe flere fastboere på Samsø. I formålet med at oprette Jordbrugsfonden har der været fokus på at (gen)etablere landbrugsdrift på øen. Set i et samfundsperspektiv føjes den oprettede jordbrugsfond til flere af SamsØkologisk eksisterende aktiviteter. Jordbrugsfonden på Samsø har skabt ringe i vandet og resulteret i en landsdækkende Jordbrugsfond, med fokus på opkøb af landbrugsjord til økologisk produktion.

\section{E. Evaluering}

Fokus i projektet "Det samfundsnyttige landbrug" har været at øge mulighederne for, at de økologiske landbrug kan overleve. Som tidligere nævnt har det dog være svært at bryde med de konventioner og taget-for-givet forestillinger, der stadig er fremherskende omkring driften af landbrug. I arbejdet med at skabe nye bæredygtige forretningsmodeller er det derfor ikke blot nødvendigt at gøre op med egne forestillinger om, hvordan man driver virksomhed, men også med konventionerne i det omkringliggende samfund.

I Asmussens (2017) evaluering af hele projektet "Det samfundsnyttige landbrug" skrives, at der har været problemer med at få de økonomiske resultater til at leve op til budgetterne, samt at skaffe finansiering til projekterne. Det understreges, at det er vigtigt at få lagt en klar plan for projektets fremdrift, fordi aktiviteterne ellers af tidsmæssige årsager nemt kan ”drukne” i praktiske gøremål. Der konkluderes:

I et fortolkende lys kan umiddelbart rejses et paradoks i forholdet mellem idealisten, hvor fokus på miljømæssig og social bæredygtighed er hæmmet af det, der også er det konventionelle landbrugs udfordringer - nemlig at skaffe kapital nok til at udvikle sin bedrift/virksomhed. Et spørgsmål kan være, om der er brug for at fokusere mere på den forretningsmæssige og finansielle tænkning, for at kunne udvikle den miljømæssige og sociale tænkning?

(Kilde: Asmussen, 2017:8)

Dette sidste citat giver anledning til at understrege vigtigheden af, at der skabes ikke blot en horisontal sammenhæng i de økonomiske, miljømæssige og sociale lag i skabelsen af bæredygtige forretningsmodeller. Den vertikale integration mellem lagene er i høj grad også nødvendige for at 
skabe økonomisk bæredygtige forretningsmodeller (Ostervalder \& Pigneur, 2010), der samtidig giver mulighed for at have fokus på miljøvenlige produktionsmetoder og skabelse af social værdi i lokalsamfundet, som det beskrives i TLBMC- modellen (Joyce \& Paquin, 2016).

\section{F. Konklusion}

I denne artikel er Raworth's Doughnut model (2017) samt Joyce \& Paquin's TLBMC-model (2016) blevet anvendt til at se på to udvalgte cases fra "Det samfundsnyttige landbrug". Formålet med dette har været at vise, hvordan bæredygtige forretningsmodeller kan udvikles på baggrund af både de teoretiske ideer og erfaringerne fra casene. Artiklen har med udgangspunkt i Raworth's (2017) økonomiske teori, kombineret med nye teorier om bæredygtige forretningsmodeller (Bocken et. al., 2014; Brix 2020; Geissdoerfer et. al., 2018; Joyce \& Paquin, 2016; Kringelum, 2017; Raworth, 2017) sat fokus på, hvordan grundlæggende taget-for-givet antagelser om økonomi, produktion og afsætning kan virke begrænsende på de forretningsmodeller, der udvikles af virksomhedsledere. Set ud i fremtiden giver et øget fokus på netværksdannelse, samarbejde, digitalisering samt nye måder at skaffe kapital, samt innovative muligheder for at skabe organisationer ud fra bæredygtige mål og værdier. Det er vigtigt at understrege, at casene angiver muligheder for nytænkning, men også har haft vanskeligheder i deres opstart og givet udfordringer med at skabe sammenhæng mellem vision og praksis. Der er et fortsat stort arbejde med at bryde med de gængse taget-for-givet antagelser fra klassisk økonomisk tænkning samt konventioner om virksomhedsdrift i det danske landbrug.

For den læser, der gerne vil udfolde Kate Raworths (2017) ideer og udvikle egne bæredygtige forretningsmodeller kan følgende spørgsmål være vigtige at stille:

* Vil øget produktion og lavere priser bringe os vækst?

* Vil øgede investeringer i produktionsfaciliteter give os en bedre fremtid?

* Hvordan kan vores produkter tilføres yderligere værdi for forbrugeren?

* Hvordan kan der skabes et tættere tilhørsforhold og tillidsforhold mellem producent og forbrugere?

* Er der muligheder i nye samarbejder, netværk?

* Kan der etableres nye distributionskanaler?

* Hvordan kan økonomisk rentabilitet integreres med miljøhensyn og social værdiskabelse, således at en vertikalt sammenhængende forretningsmodel opstår? 


\section{Referencer}

Asmussen, T. (2017). Evaluering - Det samfundsnyttige landbrug.

http://samfundsnyttigtlandbrug.dk/media/1757308/evaluering-thomas-asmussen-24-05-2017.pdf (Tilgået d. 01.02.2020).

Bocken, N.M.P., Short, S.W., Rana, P., \& Evans S. (2014). A litterature and practice review to develop sustainable business model archetypes. Journal of Cleaner Production, 65, 42-56.

https://doi.org/10.1016/j.jclepro.2013.11.039

Brix J. (2020). Building capacity for sustainable innovation: A field study of the transition from exploitation to exploration and back again. Journal of Cleaner Production, 268.

https://doi.org/10.1016/j.jclepro.2020.122381

Bronk, K. C., King, P. E., \& Matsuba, M. K. (2013). An introduction to exemplar research: A definition, rationale, and conceptual issues. In Matsuba M. K., King P. E., \& Bronk K. C. (Eds.), Exemplar Methods and Research: Strategies for Investigation. New Directions for Child and Adolescent Development, 142, 1-12. https://doi.org/10.1002/cad.20045

Chesbrough, H. (2010). Business Model Innovation: opportunities and and barriers. Long Range Planning. 43(2-3), 354-363. https://doi.org/10.1016/j.lrp.2009.07.010

Det samfundsnyttige landbrug - http://samfundsnyttigtlandbrug.dk/om-projektet (Tilgået d. 01.02.2020).

Egholm Folkefarm - Gården i byen - http://samfundsnyttigtlandbrug.dk/cases/egholm-folkefarmgaarden-i-byen (Tilgået d. 01.02.2020).

Geissdoerfer M., Vladimirova, D., Evans, S. (2018). Sustainable business model innovation: A review. Journal of Cleaner Production, 198, 401-416. https://doi.org/10.1016/j.jclepro.2018.06.240

Hersted L. \& Madsen C. Ø. (2018). Polyphonic Inquiry for Team Development, Learning and Knowledge Production. In Madsen, C. Ø.., Larsen, M. V., Hersted, L., Rasmussen, J. G. Relational Research and Organization Studies. New York. Routledge. 85-116.

https://doi.org/10.4324/9780429507557-5

Indravan I. W. (2018). Book Review. Doughnut Economics. International Journal of Economics, Management and Accounting, 26(2), 499-503. 
Joyce, A., Paquin, R. L. (2016). The triple layered business model canvas: A tool to design more sustainable business models. Journal of Cleaner Production, 1474-1486.

https://doi.org/10.1016/j.jclepro.2016.06.067

Kringelum, L. B. (2017). Trancending Organizational Boundaries: Exploring intra- and interorganizational processes of business model innovation in a port authority. Aalborg University.

Marshall, A. (1890). Principles of Economics. London. Mackmillan.

Nicoletti, M. Lutti, N., Souza, R. Pagotto, L. (2019). Social and organizational learning in the adaption to the process of climate change: The case of a Brazilian thermoplastic resins and petrochemical company. Journal of Cleaner Production, 226, 748-758.

https://doi.org/10.1016/j.jclepro.2019.04.058

Osterwalder, A., Pigneur, Y. (2010). Business Model Generation: A Handbook for Visionaries, Game Changers, and Challengers. Hoboken New Jersey. Wiley \& Sons.

https://doi.org/10.1111/j.1540-5885.2012.00977_2.x

Porter, M., Kramer, M. (2011). Creating shared value. Harvard Business Review, (Feburary).

Raworth, K., (2017). Doughnut Economics - Seven Ways to Think Like a 21st-Century Economist. United Kingdom. Penguin Random House. https://doi.org/10.33568/rbs.2409

Richardson, J. (2008). The business model: An integrative framework for strategy execution. Strategic Change, 17 (5-6), 133-144. https://doi.org/10.1002/jsc.821

SamsØkologisk - http://samfundsnyttigtlandbrug.dk/cases/samsoekologisk (Tilgået 01.02.2020).

Savitz, A. (2012). The Triple Bottom Line: How Today's Best run Companies Are Achieving Economic, Social and Environmental Succes - and How You Can Too. San Francisco. John Wiley \& Sons.

SEGES (2016). SEGES - Prognose for landbrugets økonomiske resultater 2016-2019.

https://svineproduktion.dk/Publikationer/Kilder/Notater/2016/1618 (Tilgået d. 01.02.2020).

Smith, A. (1776). An Inquiry into the Nature and Causes of the Wealth of Nations. London. W. Strathan and T. Codell.

Stubbs, W., Cocklin, C. (2008). Conceptualizing a "Sustainablility business model”. Organization \& Environment, 21(2), 103-127. https://doi.org/10.1177/1086026608318042 
DN (2017). Sådan ligger landet - tal om landbruget 2017, Danmarks Naturfredningsforening. https://www.dn.dk/om-os/publikationer/sadan-ligger-landet/ (Tilgået 01.02. 2020). www. Jordbrugsfonden.dk (Tilgået 01.02. 2020). 